\title{
Harvest Date Effect on Forage Yield, Botanical Composition, and Nutritive Value of Novel Legume-Grass Mixtures
}

\author{
Samuel Peprah 1므, Enkhjargal Darambazar ${ }^{1}$, Bill Biligetu ${ }^{2}$, Alan D. Iwaasa ${ }^{3}$, Kathy Larson ${ }^{4}$, \\ Daalkhaijav Damiran ${ }^{1}$ a and Herbert A. Lardner ${ }^{1, * \mathbb{D}}$ \\ 1 Department of Animal and Poultry Science, University of Saskatchewan, Saskatoon, SK S7N 5A8, Canada; \\ sampep20@gmail.com (S.P.); end172@mail.usask.ca (E.D.); daal.damiran@usask.ca (D.D.) \\ 2 Department of Plant Sciences, College of Agriculture and Bioresources, University of Saskatchewan, \\ Saskatoon, SK S7N 5A8, Canada; bill.biligetu@usask.ca \\ 3 Agriculture and Agri-Food Canada, Swift Current Research and Development Centre, Swift Current \\ Saskatchewan, SK S9H 3X2, Canada; alan.iwaasa@canada.ca \\ 4 Department of Agricultural and Resource Economics, College of Agriculture and Bioresources, University of \\ Saskatchewan, Saskatoon, SK S7N 5A8, Canada; kathy.larson@usask.ca \\ * Correspondence: bart.lardner@usask.ca
}

check for updates

Citation: Peprah, S.; Darambazar, E.; Biligetu, B.; Iwaasa, A.D.; Larson, K.; Damiran, D.; Lardner, H.A. Harvest Date Effect on Forage Yield, Botanical Composition, and Nutritive Value of Novel Legume-Grass Mixtures. Agronomy 2021, 11, 2184. https:// doi.org/10.3390/agronomy11112184

Academic Editor: Agnes van den Pol-van Dasselaar

Received: 15 September 2021

Accepted: 27 October 2021

Published: 29 October 2021

Publisher's Note: MDPI stays neutral with regard to jurisdictional claims in published maps and institutional affiliations.

Copyright: (c) 2021 by the authors. Licensee MDPI, Basel, Switzerland. This article is an open access article distributed under the terms and conditions of the Creative Commons Attribution (CC BY) license (https:// creativecommons.org/licenses/by/ $4.0 /)$.

\begin{abstract}
The potential for novel forage mixtures to address reduced herbage for late season grazing was investigated. Forage legumes, sainfoin (Onobrychis viciifolia Scop.) (SF) cvs. AC Mountainview, Shoshone, and Nova (MountainSF, ShoshoneSF, and NovaSF), cicer milkvetch (Astragalus cicer L.) cv. AC Veldt (CMV), Canadian milkvetch (Astragalus canadensis L.) cv. Great Plains (CaMV), and alfalfa (Medicago sativa L.) cv. AC Yellowhead (ALF) were evaluated in binary mixtures with meadow bromegrass (Bromus riparius Rehm.) cv. Admiral (MBG), hybrid bromegrass (B. riparius $\times$ B. inermis Leyss.) cv. AC Success (HBG) and Russian wildrye [Psathyrostachys junceus (Fisch.) Nevski.] cv. Tom (RWR) for yield, botanical composition, and nutritive value on July and September harvest dates at Saskatoon and Swift Current, Saskatchewan, Canada from 2016 to 2018. Hybrid bromegrass-legume mixture produced $16-38 \%$ greater forage compared to RWR-legume (7.5 vs. $5.6 \mathrm{Mg} \mathrm{ha}^{-1}$ in July and 6.1 vs. $5.1 \mathrm{Mg} \mathrm{ha}^{-1}$ in September at Saskatoon, and 3.2 vs. $2.0 \mathrm{Mg} \mathrm{ha}^{-1}$ in July at Swift Current). MountainSF and ALF had the greatest legume contribution to total yield at July harvest at Swift Current $(67.7 \pm 3.2 \%)$ and Saskatoon $(62.1 \pm 2.1 \%)$, respectively, while CaMV had lowest composition at Swift Current $(20.2 \pm 2.5 \%)$ and Saskatoon $(12.6 \pm 3.5 \%)$. The CMV and ALF-grass mixtures at Saskatoon and legume-RWR mixtures at both sites in July had greatest CP content. The July harvest had greatest yield, legume content and nutritive value compared to the September harvest at both sites. Study results suggest if yield is the objective, then either ALF or CMV with HBG may be considered. If nutritive value is the goal, any legume with RWR is an option. Finally, ALF or CMV in mixture with either HBG or RWR could be summer or fall stockpile forage in the Northern Great Plains of western Canada.
\end{abstract}

Keywords: forage yield; mixtures; nutritive value; botanical composition

\section{Introduction}

Sustainable beef production in the semiarid region of the Northern Great Plains of North America depends on forages of sufficient yield and quality during the grazing season. However, during late season, when temperatures are hottest a 'summer slump' or period of reduced growth is exhibited by cool-season grasses in pasture mixtures [1].

Legumes can compensate for grasses during this period, contributing to pasture productivity and forage nutritive value through $\mathrm{N}$ fixation, greater crude protein (CP), and digestible fiber [2]. Legumes can extend forage utilization by allowing for increased stock density on pasture [3,4]. Alfalfa (ALF, Medicago sativa L.) is a common legume due to its wide adaptation despite the risk of frothy ruminant bloat [5]. Alfalfa (M. sativa spp. 
falcata L.) cv. Yellowhead is a persistent, creeping-rooted, and grazing tolerant cultivar [6], yet not widely adopted by industry [7,8]. Sainfoin (SF, Onobrychis viciifolia Scop.) $[9,10]$, cicer milkvetch (CMV, Astragalus cicer L.) [11], and Canadian milkvetch (CaMV, Astragalus canadensis L.) $[4,10]$ are perennial, non-bloating legumes which could have potential for improved grazing performance. Performance information, such as biomass yield and nutritive value of these four legumes in mixture with grass species adapted to semiarid cool continental climates, such as the Northern Great Plains of Canadaa, is necessary. Meadow bromegrass (MBG, Bromus riparius Rehm.), a highly palatable grass species [12-14], has excellent recovery under intensive rotational grazing [15]. High yield potential of MBG (cv. Admiral) compared to Fleet MBG was reported in both Brown and Dark Brown soil zones in Western Forage Testing Trials in western Canada [16]. Hybrid bromegrass (HBG, B. riparius Rehm. $\times$ B. inermis Leyss.) is a dual-purpose forage used for both hay and pasture systems $[17,18]$. Yield and quality of HBG has shown great potential for use in beef production systems in western Canada [14,19]. Hybrid bromegrass (cv. Success) produced greater yield and higher CP content compared to MBG (cv. Fleet) in the Brown soil zone of Saskatchewan [20]. Russian wildrye (RWR, Psathyrostachys junceus [Fisch.] Nevski) is an excellent forage for all classes of livestock and retains greater CP than most grasses after maturity [21]. Russian wildrye cv. Tom yielded greater forage biomass than RWR cultivars Swift and Tetracan harvested as hay and pasture at Saskatoon, Saskatchewan [22].

Beef producers are interested in new stockpiled forage research, due to the stockpile grazing system's economic benefits [23]. The objectives of this study were to evaluate binary mixtures of novel legume and grass varieties for stockpile grazing and the effects of harvest date on yield, legume proportion, and nutritive value in the Brown and Dark Brown soil zones in Saskatchewan. These sites (soil zones) are representative of semiarid continental environments.

\section{Materials and Methods}

\subsection{Research Location, Experimental Design, and Treatments}

A 3-yr study was conducted at two sites in Saskatchewan, Canada: (i) Agriculture and Agri-Food Canada Saskatoon Research Farm $\left(52^{\circ} 04^{\prime}\right.$ N, $108^{\circ} 08^{\prime}$ W) (SASK) and (ii) Agriculture and Agri-Food Canada Swift Current Research and Development Centre $\left(50^{\circ} 16^{\prime} \mathrm{N} 107^{\circ} 44^{\prime} \mathrm{W}\right)$ (SWIFT). Soil at SASK site is classified as an Orthic Dark Brown Chernozem, Shellbrook-Hamlin association on a nearly level topography of very fine sandy loam to loam texture [24]. Soil at SWIFT site is classified as Orthic Brown Chernozem, Swinton association of a silt-loam texture on a gently sloping topography [25].

Monthly temperature $\left({ }^{\circ} \mathrm{C}\right.$ ) and total precipitation (mm) data (2015 to 2018) and long-term average (LTA; 30-yr) were obtained from SASK and SWIFT (www.climate. weatheroffice.ec.gc.ca (accessed on 15 December 2018)) based weather stations located $1 \mathrm{~km}$ from each site.

In spring 2015, composite soil samples were collected at both sites from individual plots at a depth of $15 \mathrm{~cm}$ and analyzed for available N and P (ALS Laboratory Group, Saskatoon, SK, Canada). At SWIFT and SASK, average soil N and P levels were 34 and 36, and 6 and $26 \mathrm{~kg} \mathrm{ha}^{-1}$, respectively. Based on soil test recommendations [26], no fertilizer was applied at SWIFT, however, N-P-K (11-52-0) fertilizer was applied at $38.4 \mathrm{~kg} \mathrm{ha}^{-1}$ post-seeding at the SASK site. While no herbicide was applied at SASK site, glyphosate [(N-(phosphonomethyl) glycine)] was applied at 2.5 and $2.2 \mathrm{~L} \mathrm{ha}^{-1}$, respectively, for pre-seeding weed control (20 May 2015) at SWIFT.

\subsection{Treatments}

Four legume species and six cultivars (ALF cv. AC Yellowhead, CMV cv. AC Veldt, CaMV cv. Great Plains, SF cvs. Mountainview, Nova, and Shoshone) and three grass species and cultivars (MBG cv. Admiral, HBG cv. AC Success, and RWR cv. Tom) were seeded 28 and 29 May 2015 at SWIFT and SASK, respectively. The experiment was designed as a factorial completely randomized design (CRD) with four replications of 18 treatment 
combinations (ALF + MBG; ALF + HBG; ALF + RWR; CMV + MBG; CMV + HBG; CMV + RWR; CaMV + MBG; CaMV + HBG; CaMV + RWR; MountainSF + MBG; MountainSF + HBG; MountainSF + RWR; NovaSF + MBG; NovaSF + HBG; NovaSF + RWR; ShoshoneSF + MBG; ShoshoneSF + HBG; ShoshoneSF + RWR). Mixed-row seeding at SWIFT was accomplished with a plot seeder (Fabro Ltd., Swift Current, SK, Canada) equipped with zero-till disk openers and on-row packing wheels and at SASK with a Hege plot seeder equipped with double disk openers. Seeding depth was $1.9 \mathrm{~cm}$ with rows spaced $30 \mathrm{~cm}$ apart and $6 \mathrm{~m}$ in length at both sites and seeding rates of 100 pure live seed (PLS) $\mathrm{m}^{-2}$ for SF entries and 167 PLS $\mathrm{m}^{-2}$ for all others. Plots were $1.2 \times 6 \mathrm{~m}^{2}$, with 4 rows at SASK and 6 rows at SWIFT. At SASK, guard rows of Kirk crested wheatgrass (CWG, Agropyron cristatum (L.) Gaertn.) and at SWIFT, guard rows of creeping red fescue [Festuca rubra L. ssp. arenaria (Osbeck) F. Aresch.] were established. At SWIFT, plots were enclosed using deer fence (Deer Fence Canada Inc., Dunrobin, ON, Canada) to prevent wildlife grazing.

\subsection{Forage Yield, Botanical Composition, and Nutritive Value}

Forages were harvested in July (early) (full bloom stage) or September (late) at both sites, with half of the plots harvested July, and remaining half in September. At SWIFT, early harvest was 5, 11, and 3 July, while late harvest was 13 and 6 September, and 30 August in 2016, 2017, and 2018, respectively. At SASK, early harvest was 12, 7, and 23 July and late harvest was 20, 7 and 9 September in 2016, 2017, and 2018, respectively. A $0.6 \times 5.0-\mathrm{m}^{2}$ area was cut to a $3-\mathrm{cm}$ stubble height using a flail plot harvester (Swift Machine and Welding, Swift Current, SK, Canada) and a grass plot harvester Haldrup F-55 (Haldrup GmbH, Ilshofen, Germany) at SWIFT and SASK sites, respectively. The remaining forage was removed from the plots.

Forage dry matter yield (DMY), botanical composition (legume or grass contribution to total DMY), and nutritive value were evaluated, with DM determined by weighing each of four fresh samples per treatment, drying in a forced air oven at $60{ }^{\circ} \mathrm{C}$ for $48 \mathrm{~h}$, and re-weighing. Botanical composition was determined by clipping a 1-m linear row length (center row) within each replicate $(n=4)$ plot and hand separating into grass and legume components, which were then dried in a forced air oven at $60^{\circ} \mathrm{C}$ for $48 \mathrm{~h}$, re-weighed, and composition was calculated based on DM of individual species.

Dried samples ( $\mathrm{n}=4$ per treatment) were ground through a 1-mm screen using a Wiley mill (Thomas-Wiley, Philadelphia, PA, USA) and analyzed for crude protein (CP), neutral detergent fiber (NDF), acid detergent fiber (ADF), in vitro organic matter digestibility (IVOMD), acid detergent lignin (ADL), Ca, P, and K. Sequential NDF and ADF were determined using an ANKOM ${ }^{200}$ fiber analyzer (Model 200; ANKOM; Fairport, NY, USA). The ADL was analyzed through the Klason technique [27]. Total N was determined using the micro-Kjeldahl method [28] and was multiplied by 6.25 to determine CP content. Calcium was determined using an atomic absorption spectrophotometer [28], while total P was analyzed using a spectrophotometer (Method 946.06, AOAC, 2012; Pharmacia, LKB-Ultraspec ${ }^{\circledR}$ III, Stockholm, Sweden; [28]). Potassium was determined using the method adapted from Steckel and Flannery [29]. The IVOMD was determined using the procedure developed by Tilley and Terry [30] and described by Damiran et al. [31]. Ash was determined by heating at $600{ }^{\circ} \mathrm{C}$ for $4 \mathrm{~h}$ (Method 923.03; AOAC, 2012 [28]). Total digestible nutrients (TDN) were calculated using the grass-legume Penn State equation according to Adams [32].

\subsection{Statistical Analysis}

Comparison of forages by sites and forage $\times$ harvesting date interactions are not reported, because they were not central to the objective of evaluating the forage mixtures included in this study. Therefore, data are presented by site and harvesting date. Data were subjected to an analysis of variance using the MIXED procedure of SAS 9.4 [33] for a completely randomized design (CRD) and with a $2 \times 4$ factorial arrangement of treatments 
as a split-plot design with legume as the main plot and grass as the subplot with four replications.

The model used was $Y_{i j}=\mu+$ Legume $_{i}+$ Grass $_{j}+\left(\right.$ Legume $\times$ Grass $_{i j}+e_{i j}$, where $\mathrm{Y}_{\mathrm{ij}}=$ response variable; $\mu=$ mean; legumes (Legume) and grasses (Grass) in binary mixtures were both fixed effects; Legume $e_{i}=$ legumes included in binary mixtures (ALF cv. AC Yellowhead, CMV cv. AC Veldt, CaMV cv. Great Plains, SF cvs. Mountainview, Nova, and Shoshone); Grass $_{j}=$ grasses included in binary mixtures (MBG cv. Admiral, HBG cv. AC Success, and RWR cv. Tom); and error was $\mathrm{e}_{\mathrm{ij}}$.

In addition, within site and within treatment (forage mixtures), data were analyzed with pair-wise comparisons to determine harvest date effect using the MIXED procedure of SAS 9.4 [33]. The model used for the analysis was: $Y_{i j}=\mu+T_{i}+e_{i j}$; where $Y_{i j}$ was an observation of the dependent variable $\mathrm{ij} ; \mu$ was the population mean for the variable; $\mathrm{T}_{\mathrm{i}}$ was the fixed effect of harvest date (July or September); and $\mathrm{e}_{\mathrm{ij}}$ was the random error associated with the observation ij. Year was treated as a random variable in all analysis because the objective was to characterize forage mixtures the entire growing life and not at individual year points. Differences between treatment means were determined using Tukey's multiple range test and considered significant at $p \leq 0.05$.

\section{Results and Discussion}

\subsection{Environmental Conditions}

In 2016, total precipitation during the growing season (April to October) was near the LTA at SASK but greater than the LTA at SWIFT site (Table 1). Total precipitation in 2017 and 2018 was much lower than the LTA at both sites. These dry conditions were particularly noticeable from June to August in 2017 and June to September in 2018 (Table 1). Monthly temperatures followed a similar pattern as the LTA at each site. Even though some variance with lower temperatures was observed in April 2018 at both sites, October 2016 at SASK, and September 2018 at SWIFT, and higher temperatures October 2015 at both sites, May 2016, and May 2018 at SASK (Table 1). The 2016 precipitation data reflected a wet season, in contrast to low rainfall seasons in 2017 and 2018 that resulted in dry conditions at both sites (Table 1).

Table 1. Monthly (April-October), annual, and long-term precipitation and temperature over 4 yrs. in Saskatoon and Swift Current, Saskatchewan, Canada.

\begin{tabular}{|c|c|c|c|c|c|c|c|c|c|c|}
\hline \multirow[b]{2}{*}{ Month } & \multicolumn{5}{|c|}{ Temperature, ${ }^{\circ} \mathrm{C}$} & \multicolumn{5}{|c|}{ Precipitation, $\mathrm{mm}$} \\
\hline & 2015 & 2016 & 2017 & 2018 & LTA + & 2015 & 2016 & 2017 & 2018 & LTA \\
\hline \multicolumn{11}{|c|}{ Saskatoon } \\
\hline April & 5.6 & 5.5 & 4.3 & -0.7 & 4.3 & 21.1 & 3.0 & 18.4 & 9.0 & 21.0 \\
\hline May & 10.1 & 13.7 & 12.1 & 14.3 & 11.1 & 6.3 & 41.6 & 46.3 & 14.5 & 41.3 \\
\hline June & 17.2 & 17.4 & 16.1 & 17.3 & 16.1 & 20.2 & 49.7 & 30.9 & 20.0 & 73.1 \\
\hline July & 20.1 & 18.7 & 19.6 & 18.7 & 18.5 & 85.1 & 58.6 & 25.5 & 31.5 & 60.3 \\
\hline August & 18.6 & 16.9 & 17.8 & 17.1 & 17.4 & 58.2 & 70.2 & 25.2 & 18.2 & 48.2 \\
\hline September & 12.9 & 11.8 & 12.8 & 7.4 & 12.3 & 50.8 & 24.1 & 29.1 & 37.8 & 31.6 \\
\hline October & 7.9 & 2.1 & 5.0 & 3.1 & 4.1 & 32.7 & 40.8 & 17.8 & 8.7 & 19.1 \\
\hline Annual & - & - & - & - & - & 292.4 & 345.1 & 243.1 & 190.0 & 353.9 \\
\hline \multicolumn{11}{|c|}{ Swift Current } \\
\hline April & 6.1 & 6.4 & 4.4 & 1.2 & 4.9 & 12.4 & 22.0 & 8.6 & 7.1 & 22.6 \\
\hline May & 10.1 & 12.4 & 12.1 & 14.4 & 10.9 & 2.3 & 129.7 & 16.4 & 14.9 & 47.9 \\
\hline June & 17.1 & 16.6 & 15.2 & 16.9 & 15.5 & 16.1 & 80.4 & 31.1 & 20.2 & 80.9 \\
\hline July & 19.0 & 17.8 & 20.4 & 18.9 & 18.4 & 96.1 & 119.0 & 7.5 & 32.0 & 53.3 \\
\hline August & 18.2 & 16.7 & 18.2 & 18.5 & 17.9 & 49.2 & 45.9 & 24.8 & 28.0 & 47.8 \\
\hline September & 12.6 & 12.2 & 13.4 & 9.2 & 12.8 & 39.0 & 37.1 & 2.5 & 41.8 & 32.5 \\
\hline October & 7.8 & 4.1 & 4.8 & 3.8 & 5.2 & 33.8 & 72.1 & 51.7 & 10.6 & 20.3 \\
\hline Annual & - & - & - & - & - & 304.0 & 522.6 & 189.2 & 182.3 & 372.1 \\
\hline
\end{tabular}




\subsection{Forage Yield}

A legume $\times$ grass interaction for DMY was not detected at SASK or SWIFT. At SASK, July harvest resulted in greater $(p<0.05)$ DMY than September harvest for Mountainview SF (MountainSF)-grass, Shoshone SF (ShoshoneSF)-grass, and legume-HBG mixtures (Table 2). At SWIFT, also, MountainSF-grass, ShoshoneSF-grass, CMV-grass, and ALF-grass mixtures $(p<0.001)$ produced greater DMY in July than in September $(p<0.001)$. The DMY of legume-HBG was highest $\left(7.5 \mathrm{Mg} \mathrm{ha}^{-1}\right)$ at SASK $(p<0.001)$, while legume-RWR yielded least at SWIFT $(p<0.001)$ among July-harvested legume-grasses (Table 2$)$.

Table 2. Forage dry matter yield of legume-grass binary mixtures in July and September harvest at Saskatoon and Swift Current, Saskatchewan, Canada.

\begin{tabular}{|c|c|c|c|c|}
\hline \multirow{2}{*}{$\begin{array}{c}\text { Site } \\
\text { Harvest Time }\end{array}$} & \multicolumn{2}{|c|}{ Saskatoon } & \multicolumn{2}{|c|}{ Swift Current } \\
\hline & July & September & July & September \\
\hline \multirow{2}{*}{\multicolumn{5}{|c|}{ Leoume }} \\
\hline & & & & \\
\hline MountainSF +-grass & $6.7 \mathrm{ab}$ & $5.2 b * *$ & $2.7 \mathrm{abc}$ & $1.7^{* * *}$ \\
\hline NovaSF-grass & $5.4 \mathrm{bc}$ & $4.4 \mathrm{bc}$ & $2.3 \mathrm{c}$ & 1.8 \\
\hline ShoshoneSF-grass & $6.8 \mathrm{ab}$ & $5.3 b^{*}$ & $2.3 b c$ & $1.4^{* * *}$ \\
\hline CMV-grass & $6.7 \mathrm{ab}$ & $7.5 \mathrm{a}$ & $3.2 \mathrm{ab}$ & $1.7^{* * *}$ \\
\hline CaMV-grass & $4.3 c$ & $3.5 c$ & $1.9 \mathrm{c}$ & 2.3 \\
\hline ALF-grass & $8.2 \mathrm{a}$ & $7.2 \mathrm{a}$ & $3.6 \mathrm{a}$ & $1.9^{* * *}$ \\
\hline SEM & 0.54 & 0.33 & 0.22 & 0.23 \\
\hline \multicolumn{5}{|l|}{ Grass } \\
\hline Legume-MBG & $5.9 \mathrm{~b}$ & $5.4 \mathrm{ab}$ & $2.8 \mathrm{a}$ & $1.8^{* * *}$ \\
\hline Legume-HBG & $7.5 \mathrm{a}$ & $6.1 a^{*}$ & $3.2 \mathrm{a}$ & $1.9^{* * *}$ \\
\hline Legume-RWR & $5.6 \mathrm{~b}$ & $5.1 \mathrm{~b}$ & $2.0 \mathrm{~b}$ & 1.7 \\
\hline SEM & 0.38 & 0.23 & 0.16 & 0.16 \\
\hline \multicolumn{5}{|l|}{$p$-value } \\
\hline Legume & $<0.001$ & $<0.001$ & $<0.001$ & 0.169 \\
\hline Grass & 0.001 & 0.010 & $<0.001$ & 0.662 \\
\hline Legume $\times$ Grass & 0.948 & 0.271 & 0.668 & 0.980 \\
\hline
\end{tabular}

Note. + MountainSF = AC Mountainview sainfoin; NovaSF = Nova sainfoin; ShoshoneSF = Shoshone sainfoin $\mathrm{CMV}=$ Veldt cicer milkvetch; CaMV = Great Plains Canadian milkvetch; ALF = Yellowhead alfalfa; MBG = Admiral meadow bromegrass; $\mathrm{HBG}=$ AC Success hybrid bromegrass; RWR = Tom Russian wildrye; grass = MBG + HBG + RWR; legume = MountainSF + NovaSF + ShoshoneSF + CMV + CaMV + ALF. The different letters within column and within legume and grass indicate significant difference at $p<0.05 . * * * * * *$ Significant at the 0.05 , 0.01 , and 0.001 probability levels within row for harvest time within each site, respectively.

Soil-climatic conditions influenced yield ranging 9.7 to $90 \%$ between the harvest dates, with greater biomass in July than in September. Foster et al. [11] reported greater mixture yield at mid-July compared to mid-September, although it was in a moister site-Melfort, SK, Canada. The current study differs for ALF, SF, and CMV-grass fall yields from a Brown soil study at SWIFT [34]. Holt and Jefferson [35] suggested that precipitation is the most important factor determining growth in semi-arid regions. Both sites had drought conditions in the last 2 yrs. of the current study (Table 1).

Success HBG-AC Longview ALF produced $6 \mathrm{Mg} \mathrm{ha}^{-1}$ under a two-cut system [36] at Melfort, SK compared to the July ALF-grass, in the present study, which yielded higher at SASK (8.2 Mg ha ${ }^{-1}$ ) and lower at SWIFT (3.6 Mg ha $\left.{ }^{-1}\right)$. Likewise, Hanna et al. [37] at Lethbridge, $\mathrm{AB}$, reported Ladak ALF-grass produced greater than Eski SF-grass, averaging 6.5 vs. $5.3 \mathrm{Mg} \mathrm{ha}^{-1}$, regardless of grass species, seeding method, or harvest year [37]. Yet grass yields in this Lethbridge Alberta study were similar to each other $\left(2.8 \mathrm{Mg} \mathrm{ha}^{-1}\right)$, indicating total yield difference was due to legume yield differences [37].

The least yielding forage mixtures were CaMV- and NovaSF-grass at both harvest dates at SASK $(p<0.001)$ and in July $(p<0.001)$ at SWIFT, which were 47.6 and $34.0 \%$ less in July, and 51.4 and 39.2\% less in September, respectively, compared to ALF-grass mixtures (Table 2). In addition, Sottie et al. [38] reported similar 2 yr yields of SF mixtures at SWIFT. July legume-RWR yield was $45 \%$ lower than ALF-grass yield at SWIFT. Goplen 
et al. [39] reported lower yield of MountainSF and NovaSF-RWR vs. ALF-grass, at 5.8 and $5.2 \mathrm{Mg} \mathrm{ha}^{-1}$, respectively, under irrigation and multiple harvest dates at Lethbridge, AB. Compared to Goplen et al. [39], July NovaSF-grass yield at SASK (5.4 Mg ha $\left.{ }^{-1}\right)$ in the current study, had similar biomass, however September yield was lower $\left(4.4 \mathrm{Mg} \mathrm{ha}^{-1}\right)$. Yield of CMV with MBG or HBG at Melfort, SK [11] was higher than the current study CMV-grass (11 vs. $7.5 \mathrm{Mg} \mathrm{ha}^{-1}$ at SASK), likely due to the site difference (Black Chernozem soil and high rainfall) and cultivar selection (Oxley II CMV and Fleet MBG). July CMVgrass mixtures at SWIFT accumulated greater or similar DMY to Oxley CMV-grass species (Swift RWR and Fleet MBG, yielding 1.3 and $1.7 \mathrm{Mg} \mathrm{ha}^{-1}$, respectively) in a 7-yr study [34]. Further, Biligetu et al. [34] reported that Rangelander ALF produced 2.5 $\mathrm{Mg} \mathrm{ha}^{-1} \mathrm{DMY}$ with MBG and $1.9 \mathrm{Mg} \mathrm{ha}^{-1}$ with RWR, where the ALF-MBG was higher and the ALF-RWR was similar to September ALF-grass yield at SWIFT in the present study. Acharya [40] obtained a biomass yield of $7.2 \mathrm{Mg} \mathrm{ha}^{-1}$ in multiple CMV harvests at Lethbridge, AB, which was higher than July harvest $\left(6.7 \mathrm{Mg} \mathrm{ha}^{-1}\right)$, but lower than September harvest (7.5 $\mathrm{Mg} \mathrm{ha}^{-1}$ ) of CMV-grass at SASK location.

Studies in Black soil locations [23] and at five Black soil zone Saskatchewan sites [41] reported high biomass of $4.0 \mathrm{Mg} \mathrm{ha}^{-1}$ for Paddock meadow bromgrass and AC Knowles hybrid bromegrass. Coulman [20] and McLeod et al. [7] at SASK and SWIFT under similar conditions recorded greater DMY for Success HBG compared to Fleet MBG and Tom Russian wildrye (3.4 $\mathrm{Mg} \mathrm{ha}^{-1}$ ). Over 5-yr at SWIFT, Holt and Jefferson [35] documented 3.1 $\mathrm{Mg} \mathrm{ha}{ }^{-1}$ yield for Rangelander ALF-Swift RWR, which was intermediate to July ALFgrass and legume-RWR at SWIFT in the current study (Table 2).

These results suggests that grass and legume species seeded as a mixture, play a major role in stand DM yield. Kusler [42] reported yields of $4.0 \mathrm{Mg} \mathrm{ha}^{-1}$ for Great Plains CaMV as monoculture during each of several harvest dates (June to October) at SWIFT, while the CaMV-grass in the current study, yielded lower in July than September at SWIFT and similarly across both harvest dates at SASK site (Table 2). In current study, forage mixtures had two-fold greater DMY at SASK than at SWIFT, suggesting differences in environment (SWIFT semi-arid with higher evapotranspiration) and soil type (Dark Brown vs. Brown).

However, the current study yields at SASK were well above the minimum requirement of $2.0 \mathrm{Mg} \mathrm{ha}^{-1}$, suggested for fall grazing [43]). While at SWIFT, the July CaMV-grass mixtures were slightly under the minimum requirement, and all September forage yield estimates, except CaMV-grass, failed to meet that minimum forage requirement, due to low precipitation conditions at this site (Table 2; [25]).

\subsection{Botanical Composition}

No legume $\times$ grass interaction for legume contribution to DMY was detected (Table 3). The greatest legume composition produced in July was MountainSF $(67.7 \pm 3.2 \%)$, and legumes with RWR $(59.3 \pm 2.23 \%)$ at SWIFT $(p<0.001)$, while CaMV proportion this time was the least $(12.6 \pm 3.5 \%$ and $20.2 \pm 3.2 \%$ at SASK and SWIFT, respectively) at both sites $(p<0.001)$ (Table 3). Sainfoin cultivars contributed to botanical composition similar or less than ALF at both harvest dates (Table 3). Harvest date affected MountainSF at both sites and NovaSF at SWIFT decreasing the legume proportions by September $(p<0.05)$, while CaMV-grass and legume-HBG mixtures had increased legume composition at SWIFT $(p<0.001)$ during the growing season (Table 3$)$. There were greater legume proportions in July mixtures with RWR at both sites and in September harvest of the mixtures at SASK $(p<0.001)$ (Table 3).

At SASK, NovaSF averaged 41.5\% DMY and from $43.6 \%$ in July to $32.4 \%$ DMY in September at SWIFT, where its July production was lower $(p<0.001)$ than that of MountainSF. This agreed with Acharya [44] who reported that NovaSF contributed less to the mixture compared to MountainSF at Lethbridge, AB. September SF composition on average, in the current study, contrasts with Acharya [44] and it was less compared to July and September ALF compositions at SASK. 
This study demonstrates that SF cultivars in mixed stands are less persistent, as SF declined through summer at both sites, which contrasts with breeding history of MountainSF selected for greater persistence [44]. Among grasses, HBG was 50\% or more in mixture, while MBG and RWR were 20 to $60 \%$ and 10 to $65 \%$ at July and September dates, respectively.

Table 3. Legume contribution to yield of legume-grass binary mixtures in July and September harvest at Saskatoon and Swift Current, Saskatchewan, Canada.

\begin{tabular}{|c|c|c|c|c|}
\hline \multirow{2}{*}{$\begin{array}{c}\text { Site } \\
\text { Harvest Time }\end{array}$} & \multicolumn{2}{|c|}{ Saskatoon } & \multicolumn{2}{|c|}{ Swift Current } \\
\hline & July & September & July & September \\
\hline & \multicolumn{4}{|c|}{$-\%$ of DMY } \\
\hline \multicolumn{5}{|l|}{ Legume } \\
\hline MountainSF †-grass & $54.4 \mathrm{ab}$ & $39.5 \mathrm{~cd}$ * & $67.7 \mathrm{a}$ & $37.3^{* * *}$ \\
\hline NovaSF-grass & $41.1 \mathrm{~b}$ & $41.8 \mathrm{abc}$ & $43.6 \mathrm{bc}$ & $32.4^{* *}$ \\
\hline ShoshoneSF-grass & $45.6 \mathrm{ab}$ & $42.0 \mathrm{bcd}$ & $49.9 b$ & 44.6 \\
\hline CMV-grass & $53.0 \mathrm{ab}$ & $61.5 \mathrm{a}$ & $33.6 \mathrm{~d}$ & 32.9 \\
\hline CaMV-grass & $12.6 \mathrm{c}$ & $26.1 d$ & $20.2 \mathrm{e}$ & $33.6^{* * *}$ \\
\hline ALF-grass & $61.1 \mathrm{a}$ & $58.3 \mathrm{ab}$ & $34.7 \mathrm{~cd}$ & 34.8 \\
\hline SEM & 3.47 & 4.15 & 3.15 & 4.79 \\
\hline \multicolumn{5}{|l|}{ Grass } \\
\hline Legume-MBG & $45.6 b$ & $43.7 \mathrm{~b}$ & $33.4 \mathrm{~b}$ & 33.9 \\
\hline Legume-HBG & $33.5 c$ & $41.5 b$ & $33.3 b$ & $37.3^{* * *}$ \\
\hline Legume-RWR & $67.9 \mathrm{a}$ & $59.9 a$ & $59.3 a$ & $35.3^{* * *}$ \\
\hline SEM & 2.45 & 2.94 & 2.23 & 3.39 \\
\hline \multicolumn{5}{|l|}{$p$-value } \\
\hline Legume & $<0.001$ & $<0.001$ & $<0.001$ & 0.128 \\
\hline Grass & $<0.001$ & $<0.001$ & $<0.001$ & 0.857 \\
\hline Legume $\times$ Grass & 0.915 & 0.959 & 0.053 & 0.500 \\
\hline
\end{tabular}

Note. + MountainSF = AC Mountainview sainfoin; NovaSF = Nova sainfoin; ShoshoneSF = Shoshone sainfoin; $\mathrm{CMV}$ = Veldt cicer milkvetch; CaMV = Great Plains Canadian milkvetch; ALF = Yellowhead alfalfa; MBG = Admiral meadow bromegrass; HBG = AC Success hybrid bromegrass; RWR = Tom Russian wildrye; grass $=\mathrm{MBG}+\mathrm{HBG}+\mathrm{RWR}$; legume $=$ MountainSF + NovaSF + ShoshoneSF $+\mathrm{CMV}+\mathrm{CaMV}+\mathrm{ALF}$. The different letters within column and within legume and grass indicate significant difference at $p<0.05 .{ }^{*}, * *, * *$ Significant at the $0.05,0.01$, and 0.001 probability levels within row for harvest time within each site, respectively.

Goplen et al. [39] and Pearen et al. [45] stated that rhizomatous grasses are very competitive with SF and ALF for sunlight and moisture, reducing legume composition in mixtures. Meadow bromegrass has shorter rhizomes compared to smooth bromegrass (SBG; Bromus inermis Leyss.) with limited vegetative enlargement and does not encroach rapidly on legumes and hence is less dominant in mixed stands [45]. Smooth bromegrass cytoplasm is a component of AC Success HBG, which makes it more "smooth-brome like" in appearance $[18,20]$. This may explain why MBG is less competitive than HBG in mixtures with legumes. Binary mixtures synergy can be influenced by defoliation frequency, seasonal growth rates, and tiller characteristics [46]. In an Alberta 2-cut system study [45], ALF was greater in mixtures with MBG than SBG, similarly to the July legume levels in MBG mixtures than HBG mixtures at SASK of the current study (Table 3). Species in mixed swards that have leaves higher in the canopy have a competitive advantage over species with shaded leaves [47]. This may explain the competitiveness of HBG compared to $\mathrm{MBG}$, as HBG grows taller $(>1 \mathrm{~m})$ than meadow bromegrass [17]. In a Montana study, Dubbs [48] reported that SF was less competitive with RWR than when mixed with crested wheatgrass (Agropyron cristatum), intermediate wheatgrass (Thinopyrum intermedium), or SBG, contributing only $36 \%$ of total yield, yet the current study RWR DMY was greater. Current study results suggest that SF and RWR mixtures should be avoided, and the divergence of results between SASK and SWIFTsites may be attributable in part to the cultivars selected and moisture conditions. 


\subsection{Forage Nutritive Value}

The greatest CP levels were observed for CMV-grass (100 and $88 \mathrm{~g} \mathrm{~kg}^{-1}$ in July and September, respectively; $p<0.001)$ and ALF-grass at SASK $\left(104 \mathrm{~g} \mathrm{~kg}^{-1}\right.$ in July; $\left.p<0.001\right)$, while the lowest $C P$ levels were determined in CaMV-grass ( 66 and $55 \mathrm{~g} \mathrm{~kg}^{-1}$ in July and September, respectively, $p<0.001$ ) at SASK and at SWIFT (58 $\mathrm{g} \mathrm{kg}^{-1}$ in July; $p<0.001$ ) among legumes (Tables 4 and 5). At SASK, legume-HBG mixtures had the lowest CP $\left(72 \mathrm{~g} \mathrm{~kg}^{-1} ; p<0.001\right)$ and highest NDF $\left(595 \mathrm{~g} \mathrm{~kg}^{-1} ; p<0.001\right)$ levels, while legume-RWR mixtures had the greatest $\mathrm{CP}\left(100 \mathrm{~g} \mathrm{~kg}^{-1} ; p<0.001\right)$ among July grasses. Crude protein declined during the season for the mixtures of ShoshoneSF, CaMV, and ALF with grass at SASK $(p<0.05)$, ShoshoneSF, CMV, and ALF with grass at SWIFT $(p<0.05)$, and legume-MBG and legume-RWR at both sites $(p<0.05)$.

Table 4. Nutrient composition and digestibility of legume-grass binary mixtures at July and September harvest at Saskatoon, Saskatchewan, Canada.

\begin{tabular}{|c|c|c|c|c|c|c|c|c|c|c|}
\hline \multirow{2}{*}{$\begin{array}{c}\text { Item } \\
\text { Harvest Time }\end{array}$} & \multicolumn{2}{|c|}{$\mathrm{CP}$} & \multicolumn{2}{|c|}{ NDF } & \multicolumn{2}{|c|}{ ADL } & \multicolumn{2}{|c|}{ IVOMD } & \multicolumn{2}{|c|}{ TDN } \\
\hline & July & Sept & July & Sept & July & Sept & July & Sept & July & Sept \\
\hline \multirow{2}{*}{\multicolumn{11}{|c|}{ Legume }} \\
\hline & & & & & & & & & & \\
\hline MountainSF +-grass & $76 b c$ & $68 b c$ & $568 b$ & $628 a^{* * *}$ & 86 & $108^{* *}$ & 592 & $506 b^{* * *}$ & 555 & $490 \mathrm{ab} * * *$ \\
\hline NovaSF-grass & $76 b c$ & $70 \mathrm{bc}$ & $577 \mathrm{~b}$ & $625 a^{* *}$ & 90 & $112^{* *}$ & 586 & $500 b^{* * *}$ & 558 & $464 b * * *$ \\
\hline ShoshoneSF-grass & $83 b$ & $66 b c * *$ & $575 b$ & $622 a^{* *}$ & 87 & $104^{* *}$ & 585 & $493 b^{* * *}$ & 547 & $481 \mathrm{ab} * *$ \\
\hline CMV-grass & $100 \mathrm{a}$ & $88 a$ & $531 b$ & $552 b$ & 92 & $108 *$ & 599 & $550 a^{* *}$ & 583 & $519 a^{* * *}$ \\
\hline CaMV-grass & $66 c$ & $55 c *$ & $608 \mathrm{a}$ & $651 a *$ & 85 & $100 *$ & 581 & $490 b^{* * *}$ & 567 & $470 \mathrm{ab} * * *$ \\
\hline ALF-grass & $104 a$ & $81 \mathrm{ab}{ }^{* * *}$ & $568 b$ & $629 a^{* * *}$ & 85 & $109^{* * *}$ & 600 & $508 b^{* * *}$ & 560 & $458 b$ b** \\
\hline SEM & 3.6 & 4.3 & 12.0 & 12.1 & 3.7 & 4.8 & 7.7 & 9.0 & 8.1 & 13.1 \\
\hline \multicolumn{11}{|l|}{ Grass } \\
\hline Legume-MBG & $81 b$ & $70 *$ & $558 b$ & $612^{* * *}$ & 83 & $109^{* * *}$ & 591 & $508^{* * *}$ & $576 a$ & $472^{* * *}$ \\
\hline Legume-HBG & $72 \mathrm{c}$ & 69 & $595 a$ & $619 *$ & 90 & $104^{* * *}$ & 584 & $497^{* * *}$ & $557 \mathrm{~b}$ & $485^{* * *}$ \\
\hline Legume-RWR & $100 \mathrm{a}$ & $75^{* * *}$ & $561 b$ & $621^{* * *}$ & 89 & $108^{* * *}$ & 597 & $518^{* * *}$ & $551 b$ & $484^{* * *}$ \\
\hline SEM & 2.6 & 3.1 & 8.5 & 8.5 & 2.6 & 3.4 & 5.4 & 6.4 & 5.7 & 9.3 \\
\hline \multicolumn{11}{|l|}{$p$-value } \\
\hline Legume & $<0.001$ & $<0.001$ & 0.001 & $<0.001$ & 0.699 & 0.642 & 0.390 & $<0.001$ & 0.052 & 0.018 \\
\hline Grass & $<0.001$ & 0.263 & 0.004 & 0.737 & 0.137 & 0.498 & 0.259 & 0.065 & 0.006 & 0.581 \\
\hline Legume $\times$ Grass & 0.595 & 0.970 & 0.745 & 0.515 & 0.481 & 0.779 & 1.000 & 0.617 & 0.942 & 0.428 \\
\hline
\end{tabular}

Note. + MountainSF = AC Mountainview sainfoin; NovaSF = Nova sainfoin; ShoshoneSF $=$ Shoshone sainfoin; CMV = Veldt cicer milkvetch; $\mathrm{CaMV}=$ Great Plains Canadian milkvetch; $\mathrm{ALF}=$ Yellowhead alfalfa; $\mathrm{MBG}=$ Admiral meadow bromegrass; $\mathrm{HBG}=\mathrm{AC}$ Success hybrid bromegrass; $\mathrm{RWR}=$ Tom Russian wildrye; grass $=\mathrm{MBG}+\mathrm{HBG}+\mathrm{RWR}$; legume $=$ MountainSF + NovaSF + ShoshoneSF $+\mathrm{CMV}+\mathrm{CaMV}+$ ALF. The different letters within column and within legume and grass indicate significant difference at $p<0.05 .{ }^{*}, * * * * *$ Significant at the $0.05,0.01$, and 0.001 probability levels for harvest time within each chemical composition, respectively.

As expected, NDF increased $(p<0.05)$ from July to September for all mixtures at both sites (Tables 4 and 5), except for CMV-grass at SASK $(p<0.05)$, which had the lowest September NDF (552 $\left.\mathrm{g} \mathrm{kg}^{-1} p<0.001\right)$ among legumes (Table 4). September NDF increase $(p<0.001)$ in SF-grass mixtures at both sites averaged at 625 and $584 \mathrm{~g} \mathrm{~kg}^{-1}$, at SASK and SWIFT, respectively (Tables 4 and 5). July legume-MBG mixtures at SASK were higher (576 $\left.\mathrm{g} \mathrm{kg}^{-1} ; p=0.006\right)$ in TDN than other grasses, with energy levels lower $(p<0.001)$ by fall (Table 4). Cicer milkvetch-grass exhibited had higher (550 $\left.\mathrm{g} \mathrm{kg}^{-1} ; p<0.001\right)$ IVOMD among September legumes at this site (Table 4), however, all forage IVOMD decreased $(p<0.001)$ between July and September dates, apart from ShoshoneSF and CaMV mixtures with grass at SWIFT (Tables 4 and 5). 
Table 5. Nutrient composition and digestibility of legume-grass binary mixtures at July and September harvest at Swift Current, Saskatchewan, Canada.

\begin{tabular}{|c|c|c|c|c|c|c|c|c|c|c|}
\hline \multirow{2}{*}{$\begin{array}{c}\text { Item } \\
\text { Harvest Time }\end{array}$} & \multicolumn{2}{|c|}{$\mathrm{CP}$} & \multicolumn{2}{|c|}{ NDF } & \multicolumn{2}{|c|}{ ADL } & \multicolumn{2}{|c|}{ IVOMD } & \multicolumn{2}{|c|}{ TDN } \\
\hline & July & Sept & July & Sept & July & Sept & July & Sept & July & Sept \\
\hline \multicolumn{11}{|c|}{$-\mathrm{g} \mathrm{kg}^{-1} \mathrm{DM}-$} \\
\hline Legume & & & & & & & & & & \\
\hline MountainSF †-grass & 71 & 57 & $510 \mathrm{~b}$ & $561 b^{* * *}$ & $92 a$ & 95 & $546 a$ & $522 *$ & 583 & $555 *$ \\
\hline NovaSF-grass & 69 & 56 & $548 b$ & $604 a^{* * *}$ & $91 \mathrm{a}$ & 98 & $538 \mathrm{ab}$ & $511^{* * *}$ & 578 & $539^{* *}$ \\
\hline ShoshoneSF-grass & 73 & $56^{*}$ & $548 b$ & $588 \mathrm{ab} * * *$ & $93 a$ & 104 * & $526 a b$ & 513 & 573 & $534^{* *}$ \\
\hline CMV-grass & 76 & $53 *$ & $544 \mathrm{~b}$ & $577 \mathrm{ab} * *$ & $79 b$ & $98^{* * *}$ & $552 a$ & $511 * * *$ & 597 & $545^{* * *}$ \\
\hline CaMV-grass & 58 & 56 & $592 a$ & $600 \mathrm{a} *$ & $77 \mathrm{~b}$ & $91 * * *$ & $519 b$ & 522 & 581 & $555^{* *}$ \\
\hline ALF-grass & 86 & $52 * * *$ & $529 b$ & $590 \mathrm{ab} * * *$ & $86 a b$ & $95 *$ & $541 \mathrm{ab}$ & $505^{* * *}$ & 583 & $546^{*}$ \\
\hline SEM & 6.4 & 4.8 & 11.3 & 9.4 & 3.1 & 3.0 & 6.8 & 6.4 & 11.1 & 8.3 \\
\hline \multicolumn{11}{|l|}{ Grass } \\
\hline Legume-MBG & $70 \mathrm{ab}$ & $54 * *$ & 542 & $588^{* * *}$ & $85 \mathrm{ab}$ & $98 \mathrm{ab} * * *$ & $543 a$ & $512 * * *$ & 581 & $543 b$ *** \\
\hline Legume-HBG & $63 b$ & 54 & 557 & $590 * * *$ & $82 b$ & $100 a^{* * *}$ & $525 b$ & $509 *$ & 582 & $532 b^{* * *}$ \\
\hline Legume-RWR & $84 a$ & $57 * * *$ & 537 & $583^{* * *}$ & $91 \mathrm{a}$ & $92 b$ & $544 a$ & $521 * * *$ & 584 & $563 a *$ \\
\hline SEM & 4.5 & 4.8 & 7.7 & 6.2 & 2.1 & 2.1 & 4.7 & 4.5 & 7.7 & 5.9 \\
\hline \multicolumn{11}{|l|}{$p$-value } \\
\hline Legume & 0.064 & 0.971 & $<0.001$ & 0.006 & $<0.001$ & 0.080 & 0.005 & 0.351 & 0.761 & 0.405 \\
\hline Grass & 0.005 & 0.792 & 0.179 & 0.697 & 0.010 & 0.022 & 0.007 & 0.152 & 0.979 & 0.001 \\
\hline Legume $\times$ Grass & 0.992 & 0.966 & 0.965 & 0.712 & 0.969 & 0.082 & 0.935 & 0.915 & 0.998 & 0.712 \\
\hline
\end{tabular}

Note. + MountainSF $=$ AC Mountainview sainfoin; NovaSF $=$ Nova sainfoin; ShoshoneSF $=$ Shoshone sainfoin; CMV = Veldt cicer milkvetch; $\mathrm{CaMV}=$ Great Plains Canadian milkvetch; $\mathrm{ALF}=$ Yellowhead alfalfa; $\mathrm{MBG}=$ Admiral meadow bromegrass; $\mathrm{HBG}=\mathrm{AC}$ Success hybrid bromegrass; RWR = Tom Russian wildrye; grass = MBG + HBG + RWR; legume = MountainSF + NovaSF + ShoshoneSF + CMV + CaMV+ ALF. The different letters within column and within legume and grass indicate significant difference at $p<0.05 .{ }^{*}, * * * * *$ Significant at the $0.05,0.01$, and 0.001 probability levels for harvest time within each chemical composition, respectively.

At SASK, ALF-grass contained the greatest $\mathrm{Ca}\left(7.6 \mathrm{~g} \mathrm{~kg}^{-1} ; p<0.001\right)$ in summer, while CaMV-grass $\left(3.5 \mathrm{~g} \mathrm{~kg}^{-1}\right)$ and legume-HBG were lowest $\left(4.8 \mathrm{~g} \mathrm{~kg}^{-1}\right)$ in Ca. Legume-RWR mixture was highest in $\mathrm{Ca}$ and $\mathrm{K}$, while legume-HBG exhibited lowest $(p<0.05) \mathrm{Ca}, \mathrm{P}$, and K in July. At SASK, harvest date affected P and Ca concentrations $(p<0.05)$ (Table 6) by decreasing them from July to September. As well, CMV-grass had higher $(p<0.05) \mathrm{P}$ than NovaSF-grass in September, while legume-HBG were lower than other grass mixtures (Table 6). The CMV- and ALF-grass mixtures showed higher K $(p<0.05)$ concentrations at both harvest dates. Both P and K decreased from July to September $(p<0.01)$ at SASK, while at SWIFT, only seasonal decline $(p<0.001)$ was observed in P (Table 7$)$.

In July at SWIFT, SF-grass mixtures had the highest ADL $(p<0.001)$ among legumes and legume-HBG mixtures contained less ADL ( $82 \mathrm{vs.} 91 \mathrm{~g} \mathrm{~kg}^{-1} ; p=0.010$ ) than legumeRWR, which was reverse later in the season (100 vs. $\left.92 \mathrm{~g} \mathrm{~kg}^{-1} p=0.022\right)$ (Table 5). September legume-RWR TDN was greater $\left(p=0.05 ; 562.6 \mathrm{~g} \mathrm{~kg}^{-1}\right)$ than MBG and HBG mixtures (542.6 and $532.2 \mathrm{~g} \mathrm{~kg}^{-1}$, respectively). July harvest produced higher TDN $(p=0.010)$ than September at both sites (Tables 4 and 5). The July IVOMD was lower (525 $\left.\mathrm{g} \mathrm{kg}^{-1} ; p<0.05\right)$ for legume-HBG mixture compared to MBG and RWR mixtures (542.8 and $544.0 \mathrm{~g} \mathrm{~kg}^{-1}$, respectively). Overall, September forages had lower IVOMD than July forages $(p<0.05)$ at both sites, except SWIFT CaMV mixtures. Mixed stands can produce not only more biomass than a pure stand legume, when mixing two different but appropriate species, improved pasture productivity and feed efficiency through improved pasture quality can result [49]. 
Table 6. Mineral composition of legume-grass binary mixtures at July and September harvest at Saskatoon, Saskatchewan, Canada.

\begin{tabular}{|c|c|c|c|c|c|c|}
\hline \multirow{2}{*}{$\begin{array}{c}\text { Item } \\
\text { Harvest Time }\end{array}$} & \multicolumn{2}{|c|}{$\mathrm{Ca}$} & \multicolumn{2}{|r|}{$\mathbf{P}$} & \multicolumn{2}{|c|}{ K } \\
\hline & July & September & July & September & July & September \\
\hline & \multicolumn{6}{|c|}{$-\mathrm{g} \mathrm{kg}^{-1} \mathrm{DM}-$} \\
\hline Legume & & & & & & \\
\hline MountainSF †-grass & $7.8 \mathrm{~b}$ & $9.1 \mathrm{ab}$ & 1.2 & $0.7 \mathrm{ab} * * *$ & $18.3 c$ & $13.5 c^{* * *}$ \\
\hline NovaSF-grass & $7.4 \mathrm{bc}$ & $8.9 b *$ & 1.2 & $0.7 \mathrm{~b}^{* * *}$ & $19.3 c$ & $14.5 \mathrm{bc} * * *$ \\
\hline ShoshoneSF-grass & $8.4 \mathrm{~b}$ & $7.9 \mathrm{bc}$ & 1.2 & $0.8 \mathrm{ab} * * *$ & $20.2 b c$ & $12.4 c^{* * *}$ \\
\hline CMV-grass & $9.1 b$ & $10.8 \mathrm{a} *$ & 1.3 & $0.9 a^{* * *}$ & $24.7 \mathrm{a}$ & $19.6 a^{* *}$ \\
\hline CaMV-grass & $6.0 \mathrm{c}$ & $6.4 \mathrm{c}$ & 1.2 & $0.8 \mathrm{ab} * * *$ & $18.5 c$ & $12.1 c^{* * *}$ \\
\hline ALF-grass & $12.2 \mathrm{a}$ & $9.5 \mathrm{ab} * * *$ & 1.3 & $0.9 \mathrm{ab} * * *$ & $22.6 a b$ & $17.3 \mathrm{ab} * * *$ \\
\hline SEM & 0.45 & 0.43 & 0.05 & 0.05 & 0.65 & 0.87 \\
\hline \multicolumn{7}{|l|}{ Grass } \\
\hline Legume-MBG & $8.3 b$ & 8.7ab & $1.3 a$ & $0.8^{* * *}$ & $21.1 b$ & $14.3 \mathrm{ab} * * *$ \\
\hline Legume-HBG & $7.0 \mathrm{c}$ & $8.2 b *$ & $1.2 b$ & $0.8^{* * *}$ & $17.9 \mathrm{c}$ & $14.2 b^{* * *}$ \\
\hline Legume-RWR & $10.2 \mathrm{a}$ & $9.3 \mathrm{a}$ & $1.3 a$ & $0.8^{* * *}$ & $22.8 \mathrm{a}$ & $16.3 a^{* * *}$ \\
\hline SEM & 0.32 & 0.31 & 0.03 & 0.03 & 0.46 & 0.61 \\
\hline \multicolumn{7}{|l|}{$p$-value } \\
\hline Legume & $<0.001$ & $<0.001$ & 0.355 & 0.027 & $<0.001$ & $<0.001$ \\
\hline Grass & $<0.001$ & 0.031 & 0.003 & 0.805 & $<0.001$ & 0.027 \\
\hline Legume $\times$ Grass & 0.635 & 0.952 & 0.909 & 0.991 & 0.009 & 0.650 \\
\hline
\end{tabular}

Note. + MountainSF = AC Mountainview sainfoin; NovaSF = Nova sainfoin; ShoshoneSF = Shoshone sainfoin; $\mathrm{CMV}$ = Veldt cicer milkvetch; CaMV = Great Plains Canadian milkvetch; ALF = Yellowhead alfalfa $\mathrm{MBG}=$ Admiral meadow bromegrass; $\mathrm{HBG}=\mathrm{AC}$ Success hybrid bromegrass; RWR = Tom Russian wildrye grass $=\mathrm{MBG}+\mathrm{HBG}+\mathrm{RWR}$; legume $=$ MountainSF + NovaSF + ShoshoneSF $+\mathrm{CMV}+\mathrm{CaMV}+\mathrm{ALF}$. The different letters within column and within legume and grass indicate significant difference at $p<0.05 .{ }^{*}, * *, * *$ Significant at the $0.05,0.01$, and 0.001 probability levels for harvest time within each chemical composition, respectively.

Table 7. Mineral composition of legume-grass binary mixtures at July and September harvest at Swift Current, Saskatchewan, Canada.

\begin{tabular}{|c|c|c|c|c|c|c|}
\hline \multirow{2}{*}{$\begin{array}{c}\text { Item } \\
\text { Harvest Time }\end{array}$} & \multicolumn{2}{|c|}{$\mathrm{Ca}$} & \multicolumn{2}{|r|}{$\mathbf{P}$} & \multicolumn{2}{|r|}{$\mathbf{K}$} \\
\hline & July & September & July & September & July & September \\
\hline & \multicolumn{6}{|c|}{$-\mathrm{g} \mathrm{kg}^{-1} \mathrm{DM}-$} \\
\hline Legume & & & & & & \\
\hline MountainSF +-grass & $6.0 \mathrm{~b}$ & $3.9^{* * *}$ & 1.1 & $0.6^{* * *}$ & 11.8 & 13.0 \\
\hline NovaSF-grass & $5.4 \mathrm{~b}$ & $3.9^{* *}$ & 1.2 & $0.5^{* * *}$ & 12.5 & 13.0 \\
\hline ShoshoneSF-grass & $5.8 \mathrm{~b}$ & $4.0 * *$ & 1.2 & $0.5^{* * *}$ & 13.1 & 12.6 \\
\hline CMV-grass & $5.2 b$ & $3.8^{* *}$ & 1.1 & $0.6^{* * *}$ & 11.4 & 11.6 \\
\hline CaMV-grass & $3.5 c$ & 3.6 & 1.0 & $0.4^{* * *}$ & 12.7 & 12.2 \\
\hline ALF-grass & $7.6 a$ & $3.9 * * *$ & 1.1 & $0.5^{* * *}$ & 12.9 & 11.3 \\
\hline SEM & 0.30 & 0.50 & 0.14 & 0.04 & 1.29 & 0.63 \\
\hline \multicolumn{7}{|l|}{ Grass } \\
\hline Legume-MBG & $5.7 \mathrm{a}$ & $4.0^{* * *}$ & 1.1 & $0.5^{* * *}$ & 12.4 & $11.8 \mathrm{~b}$ \\
\hline Legume-HBG & $4.8 \mathrm{~b}$ & $3.9 *$ & 1.0 & $0.5^{* * *}$ & 12.8 & $11.3 b$ \\
\hline Legume-RWR & $6.2 \mathrm{a}$ & $3.7^{* * *}$ & 1.2 & $0.5^{* * *}$ & 12.0 & $13.7 \mathrm{a}$ \\
\hline SEM & 0.21 & 0.33 & 0.10 & 0.03 & 0.87 & 0.45 \\
\hline \multicolumn{7}{|l|}{$p$-value } \\
\hline Legume & $<0.001$ & 0.996 & 0.934 & 0.139 & 0.922 & 0.290 \\
\hline Grass & $<0.001$ & 0.820 & 0.354 & 0.440 & 0.829 & $<0.001$ \\
\hline Legume $\times$ Grass & 0.873 & 1.000 & 1.000 & 0.090 & 0.579 & $<0.001$ \\
\hline
\end{tabular}

Note. $\uparrow$ MountainSF $=$ AC Mountainview sainfoin; NovaSF $=$ Nova sainfoin; ShoshoneSF $=$ Shoshone sainfoin $\mathrm{CMV}=$ Veldt cicer milkvetch; $\mathrm{CaMV}=$ Great Plains Canadian milkvetch; ALF = Yellowhead alfalfa; MBG = Admiral meadow bromegrass; HBG = AC Success hybrid bromegrass; RWR = Tom Russian wildrye; grass = MBG $+\mathrm{HBG}+\mathrm{RWR}$; legume $=$ MountainSF + NovaSF + ShoshoneSF $+\mathrm{CMV}+\mathrm{CaMV}+\mathrm{ALF}$. The different letters within column and within legume and grass indicate significant difference at $p<0.05 .{ }^{*}, * * * * *$ Significant at the 0.05 , 0.01 , and 0.001 probability levels for harvest time within each chemical composition, respectively.

Beef cattle performance is reflective of good forage nutritive value [50]. Allowing standing forage to accumulate for grazing at a later period, often for fall and winter grazing 
after dormancy is considered stockpiling. Stockpiling relies on mature forages that may not meet nutrient requirements of beef cattle [51-53]. According to NASEM [54], the CP and TDN requirements for mature cows and heifers either pregnant or lactating ranges from 62 to $129 \mathrm{~g} \mathrm{~kg}^{-1}$ and 449 to $645 \mathrm{~g} \mathrm{~kg}^{-1}$, respectively. Forage CP levels at SASK were within the requirements for all mixtures, apart from CaMV-grass in September $\left(55 \mathrm{~g} \mathrm{~kg}^{-1}\right)$ (Table 4). In contrast, at SWIFT, July CaMV-grass $\left(58 \mathrm{~g} \mathrm{~kg}^{-1}\right)$ and all September mixtures did not have sufficient CP (ranged from 52 to $57 \mathrm{~g} \mathrm{~kg}^{-1}$ ) for grazing beef cows [54]. A rapid decline in $\mathrm{CP}$ for grasses is noted as they enter reproductive phenological stages with July $\mathrm{CP}$ below $7.5 \%$ and continuing to decline through fall $[49,55]$. This was consistent for the current study July legume-MBG and HBG at SWIFT (Table 5) and legume-HBG mixtures at SASK (Table 4).

Regardless of location and harvest, legume-RWR ranked highest for meeting CP requirements, except the fall harvest at SWIFT. Russian wildrye maintains forage quality, while western wheatgrass (WWG) quality declines markedly by fall [55].

All legumes with grasses except CaMV showed higher CP content regardless of location. Biligetu et al. [34] showed that ALF with WWG or RWR had higher CP level, consistent with the current study. In contrast, McGeough et al. [56] stated that CWG, MBG, WWG, northern wheatgrass, and green needlegrass in mixture with ALF showed low protein levels ranging from 5.0 to $10.7 \%$, suggesting advanced plant maturity. All binary mixtures at both sites had similar TDN concentration, meeting beef cow nutrient requirements (440.9 to $640.5 \mathrm{~g} \mathrm{~kg}^{-1}$ ) [54].

Fiber is a major fraction of DM and is correlated with intake and digestibility $[8,54]$. However, fiber level of mixtures is mainly related to grass fiber content [34,57]. According to Van Soest [27], legumes tend to have lower fiber content compared to grasses. Legumes with less than $45.0 \%$ NDF in mixture is considered high quality, while legumes over $50.0 \%$ or grass with $60.0 \%$ NDF are considered low quality [54]. July and September forage NDF level ranged from 510 to $600.8 \mathrm{~g} \mathrm{~kg}^{-1}$ and 550.2 to $650.1 \mathrm{~g} \mathrm{~kg}^{-1}$, respectively, or medium to low quality at both sites. While SWIFT mixtures were medium quality with $600 \mathrm{~g} \mathrm{~kg}^{-1}$ or less NDF, September harvest at SASK (except CMV-grass; $550.2 \mathrm{~g} \mathrm{~kg}^{-1}$ ) contained $>600 \mathrm{~g} \mathrm{~kg}^{-1} \mathrm{NDF}$ or was low quality. This suggests that binary mixtures in Dark Brown soil zone tend to have greater fiber late season. Russian wildrye can express a juvenile growth stage after establishment, where reproductive tillers are not initiated, so that stem elongation and seed production typical of advancing phenological development do not occur [58]. This extended period of vegetative tiller development would account for lower fiber, greater CP and TDN observed for the RWR-legume mixtures in the present study. The juvenile stage typically passes one year, so reproductive tiller and seed production occurs in future years [58], consistent with the observations in the current study.

Jefferson et al. [59] reported low IVOMD values of 40.8 to $55.3 \%$ for native grasses, reflecting mature growth stage when fall harvested. Biligetu et al. [34] reported ALF, CMV, and SF with MBG or RWR harvested late summer had 43.7 to $55.9 \%$ and 51.3 to $54.8 \%$ IVOMD, respectively. Peprah et al. [8] had IVOMD values of 50.6 and 54.5\% for legumegrass mixtures at SWIFT and Lanigan SK (Thin Black soil zone), respectively, similar to the present IVOMD findings. Stockpiled October MBG at Lacombe, AB [43] had high $58 \%$ IVOMD maintaining good digestibility. Legume-MBG or RWR in the current study, with greater IVOMD values than July HBG at SWIFT, indicated that MBG similar to RWR maintains its leaves and quality late in the season [17]. As forages mature, the nutritive value of both annual and perennial species declines [53] due to decreased protein and digestibility and increased fiber, which was evident in the current study.

Beef cattle (growing, lactating, and mid-gestation) require 0.18 to $0.90 \%$ of Ca in their diet $[27,54]$. All binary mixtures in this study $\left(4\right.$ to $\left.12 \mathrm{~g} \mathrm{~kg}^{-1}\right)$ met the Ca requirement for beef cattle at both sites. Calcium level in our study was $27 \%$ greater than Jefferson et al. [59], likely due to greater legume proportion in the current study as legumes have greater $\mathrm{Ca}$ content than grasses [54]. All July forages at SASK and NovaSF-grass, ShoshoneSF-grass and legume-RWR at SWIFT met the P concentration requirement of $0.12 \%$ [50], but not 
September forages at the sites. Reduced P in September than in July at both sites suggests that mineral $P$ supplementation is required when fall grazing these mixtures. Legumes tend to take up soil $\mathrm{P}, \mathrm{K}$, and $\mathrm{S}$ at a greater rate than grasses [60], which was more consistent for SASK Dark Brown soil site with decreasing P and K concentrations, than at SWIFT Brown soil site. The ideal Ca:P ratio is 1.6:1 for beef cattle, or range of 1.6:1 to 4:1 being acceptable NASEM [54]. However, all mixtures did not meet the ideal Ca:P ratio requirements for beef cattle at either site, implying the need to supplement $P$ under stockpile grazing [43].

\section{Conclusions}

Legume-grass mixtures grown at SASK yielded two-fold greater biomass and $24 \%$ more protein compared to SWIFT mixtures. All binary mixtures could provide sufficient stockpile forage for summer/fall grazing at SASK, while all mixtures except CaMV-grass at SWIFT could provide summer but not fall stockpile grazing, as SWIFT site did not meet the minimum herbage mass requirement of $2.0 \mathrm{Mg}$ per hectare. Despite low herbage mass of legume-RWR in summer at SWIFT site, all forages had high protein at both sites, producing medium to high nutritive value forage. Even though legume-HBG had greatest legume and grass composition and had higher total herbage than legume-RWR in the summer and fall at SASK, the fall protein level was insufficient to meet beef cattle protein requirements. Current study suggests that legumes are more compatible with Russian wildrye compared to meadow or hybrid bromegrass at both sites. Conversely, hybrid bromegrass was the most compatible grass species with legumes, and thus increased total herbage of legume-grass mixtures. Finally, the optimal forage mixture for stockpile grazing will depend on the goal of the producer. If herbage yield is the objective, then either alfalfa or cicer milkvetch in mixture with hybrid bromegrass would rank high. If nutritive value is the goal, then any legume in mixture with Russian wildrye would be suitable for summer/fall stockpile grazing at SASK location, or summer stockpile grazing at SWIFT site.

Author Contributions: Conceptualization, H.A.L., A.D.I. and B.B.; formal analysis, S.P., D.D. and K.L.; funding acquisition, H.A.L. and A.D.I.; investigation, S.P.; methodology, H.A.L., A.D.I. and B.B.; project administration, H.A.L. and A.D.I.; supervision, H.A.L. and A.D.I.; writing original draft, S.P.; review and editing, H.A.L., D.D., A.D.I., B.B., K.L. and E.D. All authors have read and agreed to the published version of the manuscript.

Funding: Funding for this research was provided by Saskatchewan Agricultural Development Fund \#20130215 and the South West Saskatchewan Forage Cooperative Association Limited.

Institutional Review Board Statement: Not applicable.

Informed Consent Statement: Not applicable.

Data Availability Statement: Raw data is available upon request to Herbert A. Lardner.

Acknowledgments: Technical assistance provided by Leah Pearce, Krystal Savenkoff, George Widdifield, Russ Muri, Ed Birkedal, Lindsay Haubrich, and Elaine Walliseris is gratefully acknowledged.

Conflicts of Interest: The authors declare that the research was conducted with no conflict of interest.

\section{References}

1. Putnam, D.H.; Orloff, S.B. Forage Crops. Encyclopedia of Agriculture and Food Systems; Van Alfen, N.K., Ed.; Academic Press: Cambridge, MA, USA, 2014; pp. 381-405. [CrossRef]

2. Sleugh, B.; Moore, K.J.; George, J.R.; Brummer, E.C. Binary legume-grass mixtures improve forage yield, quality, and seasonal distribution. Agron. J. 2000, 92, 24-29. [CrossRef]

3. Cox, S.; Peel, M.; Creech, J.E.; Waldron, B.L.; Ean, J.; Zobell, D.R.; Miller, R.L.; Snyder, D.L. Forage production of grass-legume binary mixtures on intermountain western USA irrigated pastures. Crop Sci. 2017, 57, 1742-1753. [CrossRef]

4. Lardner, H.A.; Pearce, L.; Damiran, D. Evaluation of cicer milkvetch cultivars and alfalfa cultivars for nutritive value, anti-quality factors and animal preference. Sust. Agric. Res. 2019, 8, 1-10. [CrossRef] 
5. Majak, W.; McAllister, T.A.; McCartney, D.; Stanford, K.; Cheng, K.J. Bloat in Cattle; Alberta Agriculture and Rural Development: Edmonton, AB, Canda, 2003; p. 28. Available online: https://www1.agric.gov.ab.ca/\$department/deptdocs.nsf/ba3468a2a868 1f69872569d60073fde1/c147cb84919a6fd487256d430057b2cd/\$FILE/420_60-1.pdf (accessed on 25 August 2021).

6. Katepa-Mupondwa, F.; Singh, A.; Smith, S.R., Jr.; McCaughey, W.P. Grazing tolerance of alfalfa (Medicago ssp.) under continuous and rotational stocking systems in pure stands and in mixture with meadow bromegrass (Bromus riparius Rehm. syn. B. biebersteinii Roem E Schult). Can. J. Plant Sci. 2002, 82, 337-347. [CrossRef]

7. McLeod, J.G.; Muri, R.; Jefferson, P.G.; Bittman, S.; McCartney, D. Yellowhead alfalfa. Can. J. Plant Sci. 2009, 89, 653-655. [CrossRef]

8. Peprah, S.; Damiran, D.; Biligetu, B.; Jefferson, P.G.; Iwaasa, A.D.; Larson, K.; Lardner, H.A. Evaluation of cool-season binary mixtures as pasture: Herbage yield, nutritive value and beef cattle performance. Livest. Sci. 2021, 248, 1-10. [CrossRef]

9. Berard, N.C.; Wang, Y.; Wittenberg, K.M.; Krause, D.O.; Coulman, B.E.; McAllister, T.A.; Ominski, K.H. Condensed tannin concentrations found in vegetative and mature forage legumes grown in western Canada. Can. J. Plant Sci. 2011, 91, 669-675. [CrossRef]

10. Li, Y.; Iwaasa, A.D.; Wang, Y.; Jin, L.; Han, G.; Zhao, M. Condensed tannins concentration of selected prairie legume forages as affected by phenological stages during two consecutive growth seasons in western Canada. Can. J. Plant Sci. 2014, 94, 817-826. [CrossRef]

11. Foster, A.; Biligetu, B.; Darambazar, E. Forage yield and nutritive value of simple and complex grass-cicer milkvetch mixtures under two harvest management systems. Crop Sci. 2019, 59, 2876-2885. [CrossRef]

12. Sedivec, K.; Tober, D.; Duckwitz, W.; Dewald, D.; Printz, J. Grasses for the Northern Plains. In Cool Season; North Dakota State University Extension: Fargo, ND, USA, 2007; Volume 1.

13. St John, L.; Tilley, D.; Jensen, K. Plant Guide for Meadow Brome (Bromus biebersteinii); USDA-Natural Resources Conservation Service, Aberdeen Plant Materials Centre: Aberdeen, ID, USA, 2012.

14. Lardner, H.A.; Damiran, D.; McKinnon, J.J. Evaluation of 3 bromegrass species as pasture: Herbage nutritive value, estimated grass dry matter intake and steer performance. Livest. Sci. 2015, 175, 77-82. [CrossRef]

15. Ogle, D.; John, L.S.; Holzworth, L.K.; Jensen, K.B. Meadow Brome. 2006. Available online: http://plants.usda.gov/plantguide/ pdf/pg_brbi2.pdf (accessed on 3 July 2020).

16. Coulman, B. AC Admiral meadow bromegrass. In Technical Bulletin; Agriculture Canada Publisher: Saskatoon, SK, Canada, 2009.

17. Aasen, A.; Bjorge, M. Alberta Forage Manual; Alberta Agriculture and Rural Development: Edmonton, AB, Canada, 2009; Available online: https://www1.agric.gov.ab.ca/\$Department/deptdocs.nsf/all/agdex16/\$FILE/120_20-1_2009.pdf (accessed on 25 August 2021).

18. Coulman, B. Knowles hybrid bromegrass. Can. J. Plant Sci. 2004, 84, 815-817. [CrossRef]

19. Ferdinandez, Y.S.N.; Coulman, B.E. Nutritive values of smooth bromegrass, meadow bromegrass, and meadow $x$ smooth bromegrass hybrids for different plant parts and growth stages. Crop Sci. 2001, 41, 473-478. [CrossRef]

20. Coulman, B. Success hybrid bromegrass. Can. J. Plant Sci. 2006, 86, 745-747. [CrossRef]

21. Ogle, D.; John, L.S.; Cornwell, J.; Holzworth, L.K.; Majerus, M.; Tober, D.; Jensen, K.B.; Sanders, K.E.; John, L.S. Plant Guide for Russian Wildrye (Psathyrostachys junceus); USDA-Natural Resources Conservation Service, Aberdeen Plant Materials: Aberdeen, ID, USA, 2012.

22. McLeod, J.G.; Jefferson, P.G.; Muri, R.; Lawrence, T. Tom Russian wildrye. Can. J. Plant Sci. 2003, 83, 789-791. [CrossRef]

23. Lardner, H.A.; Ward, C.I.; Darambazar, E.; Damiran, D. Comparison of cool season perennial grasses for forage production and nutritive value, steer performance and economic analysis. Prof. Anim. Sci. 2013, 29, 403-412. [CrossRef]

24. Saskatchewan Soil Survey. The Soils of Poplar Valley Rural Municipality, Number 12. Saskatchewan Soil Survey Staff; University of Saskatchewan: Saskatoon, SK, Canada, 1999.

25. Saskatchewan Soil Survey. The Soils of Rural Municipality of Swift Current, Number 137. Saskatchewan Soil Survey Staff; University of Saskatchewan: Saskatoon, SK, Canada, 1990.

26. Government of Saskatchewan. Fertilizing Seeded Forages in Saskatchewan. 2016. Available online: https://www.saskatchewan. $\mathrm{ca} /$ business / agriculture-natural-resources-and-industry/agribusiness-farmers-and-ranchers/crops-and-irrigation/soilsfertility-and-nutrients/fertilizing-seeded-forages-in-saskatchewan (accessed on 25 August 2021).

27. Van Soest, P.J. Nutritional Ecology of the Ruminant, 2nd ed.; Cornell University Press: Ithaca, NY, USA, 1994.

28. AOAC. Official Methods of Analysis, 19th ed.; AOAC: Gaithersburg, MD, USA, 2012.

29. Steckel, J.E.; Flannery, R.L. Automatic determination of phosphorus, potassium, calcium and magnesium in wet digestion solutions of plant tissue. In Proceedings of the Technicon Symposium of Auto Analytical Chemistry, New York, NY, USA, 8-10 September 1965.

30. Tilley, J.M.A.; Terry, R.A. A two-stage technique for the in vitro digestion of forage crops. J. Brit. Grassl. Soc. 1963, 18, 104-111. [CrossRef]

31. Damiran, D.; DelCurto, T.; Bohnert, D.W.; Findholt, S.L. Comparison of techniques and grinding sizes to estimate digestibility of forage based ruminant diets. Anim. Feed Sci. Technol. 2008, 141, 15-35. [CrossRef]

32. Adams, R.S. Dairy nutrition. In Dairy Reference Manual, 3rd ed.; Walker, C., Ed.; Northeast Regional Agricultural Engineering Service: Ithaca, NY, USA, 1995.

33. SAS Institute. SAS User's Guide 2014: Statistics; SAS Institute: Cary, NC, USA, 2014. 
34. Biligetu, B.; Jefferson, P.G.; Muri, R.; Schellenberg, M.P. Late summer forage yield, nutritive value, compatibility of warm-and cool-season grasses seeded with legumes in western Canada. Can. J. Plant Sci. 2014, 94, 1139-1148. [CrossRef]

35. Holt, N.; Jefferson, P.G. Productivity and sustainability of four grazed grass-alfalfa mixtures. Can. J. Plant Sci. 1999, 79, 83-89. [CrossRef]

36. Foster, A.; Vera, C.L.; Malhi, S.S.; Clarke, F.R. Forage yield of simple and complex grass-legume mixtures under two management strategies. Can. J. Plant Sci. 2014, 94, 41-50. [CrossRef]

37. Hanna, M.R.; Kozub, G.C.; Smoliak, S. Forage production of sainfoin and alfalfa on dryland in mixed and alternate row seedings with three grasses. Can. J. Plant Sci. 1977, 57, 61-70. [CrossRef]

38. Sottie, E.T.; Acharya, S.; McAllister, T.; Iwaasa, A.; Thomas, J.; Wang, Y. Performance of alfalfa/sainfoin mixed pastures and grazing steers in western Canada. Prof. Anim. Sci. 2017, 33, 472-482. [CrossRef]

39. Goplen, B.P.; Richards, K.W.; Moyer, J.R. Sainfoin for Western Canada; Agriculture Canada Publisher: Ottawa, ON, Canada, 1991.

40. Acharya, S.N. Veldt cicer milkvetch. Can. J. Plant Sci. 2009, 89, 511-513. [CrossRef]

41. Lardner, H.A.; Wright, S.B.M.; Cohen, R.D.H.; Curry, P.; MacFarlane, L. The effect of rejuvenation of Aspen Parkland Ecoregion grass-legume pastures on dry matter yield and forage quality. Can. J. Plant Sci. 2000, 80, 781-791. [CrossRef]

42. Kusler, J. Comparing Simple and Complex Native Forage Mixtures in Southern Saskatchewan. Master's Thesis, University of Saskatchewan, Saskatoon, SK, Canada, August 2009.

43. Alberta Agriculture and Forestry. Agronomic Management of Stockpiled Pastures, Agdex 420/56-4. 2008. Available online: https: / / open.alberta.ca/ dataset/d2147f9c-0b6f-46f0-861c-027c2ba6faf2/ resource/8936bac7-43b4-4f3b-bee2-c76395c4f9 2e/download/2008-420-56-4.pdf (accessed on 25 August 2021).

44. Acharya, S.N. AAC Mountainview sainfoin (Onobrychis viciifoila subsp. Viciifolia). Can. J. Plant Sci. 2015, 95, 603-607. [CrossRef]

45. Pearen, J.R.; Baron, V.S.; Cowan, I.W. Productivity and composition of bromegrass alfalfa mixtures for hay in the Aspen Parklands of western Canada. Can. J. Plant Sci. 1995, 75, 429-436. [CrossRef]

46. Haynes, R.J. Competitive aspects of the grass-legume association. Adv. Agron. 1980, 33, 227-261.

47. Trenbath, B.R. Biomass productivity of mixtures. Adv. Agron. 1974, 26, 177-210.

48. Dubbs, A.L. Competition between grass and legume species on dryland. Agron. J. 1971, 68, 359-362. [CrossRef]

49. Acharya, S.N.; Sottie, E.; Coulman, B.; Iwaasa, A.; McAllister, T.; Wang, Y.; Liu, J. New sainfoin populations for bloat-free alfalfa pasture mixtures in western Canada. Crop Sci. 2013, 53, 2283-2293. [CrossRef]

50. Collins, M.; Fritz, J.O. Forage quality. In An Introduction to Grassland Agriculture; Barnes, R.F., Nelson, C.J., Collins, M., Moore, K.J., Eds.; Iowa State Press: Ames, IA, USA, 2003; pp. 363-390.

51. Darambazar, E.; DelCurto, T.; Damiran, D. Changes in forage quantity and quality with continued late-summer cattle grazing a riparian pasture in eastern oregon of the United States. Sust. Agric. Res. 2013, 2, 64-76. [CrossRef]

52. Barnes, R.F.; Nelson, C.J.; Moore, K.J.; Collins, M. Forages. In The Science of Grassland Agriculture, 6th ed.; Blackwell Publishing: Ames, IA, USA, 2003; Volume 2.

53. Añez-Osuna, F.; Penner, G.B.; Damiran, D.; Jefferson, P.G.; Lardner, H.A.; McKinnon, J.J. Effects of alternate day supplementation at two levels of energy on forage utilization and performance of growing steers grazing stockpiled cool-season perennial grass pastures. Can. J. Plant Sci. 2017, 97, 510-516.

54. NASEM. Nutrient Requirement of Beef Cattle, 8th ed.; National Academies Press: Washington, DC, USA, 2016.

55. Ganskopp, D.; Bohnert, D.W. Nutritional dynamics of 7 northern Great Basin grasses. J. Range Manag. 2001, 54, 640-647. [CrossRef]

56. McGeough, E.J.; Cattani, D.J.; Koscielny, Z.; Hewitt, B.; Ominski, K.H. Annual and perennial forages for fall/winter grazing in western Canada. Can. J. Plant Sci. 2018, 98, 247-254. [CrossRef]

57. Smoliak, S.; Bezeau, L.M. Chemical composition and in vitro digestibility of range forage plants of the Stipa-bouteloua prairie. Can. J. Plant Sci. 1967, 47, 161-167. [CrossRef]

58. Lawrence, T.; Heinrichs, D.H. Growing Russian Wild Ryegrass in Western Canada; Canada Department of Agriculture: Ottawa, ON, Canada, 1977.

59. Jefferson, P.G.; McCaughey, W.P.; May, K.; Woosaree, J.; McFarlane, L. Forage quality of seeded native grasses in the fall season on the Canadian Prairie Provinces. Can. J. Plant Sci. 2004, 84, 503-509. [CrossRef]

60. Crème, A.; Rumpel, C.; Gastal, F.; Gil, M.M.; Chabbi, A. Effects of grasses and a legume grown in monoculture or mixture on soil organic matter and phosphorus forms. Plant Soil. 2016, 402, 117-128. [CrossRef] 